\title{
PENGARUH TERAPI RELAKSASI NAFAS DALAM TERHADAP TINGKAT KECEMASAN DAN LAMA PERSALINAN KALA I DAN II DI BPM WILAYAH KLATEN
}

\author{
Henik Istikhomah, Murwati \\ Kementerian Kesehatan Politeknik Kesehatan Surakarta Jurusan Kebidanan
}

\begin{abstract}
Deep Relaxation Therapy, Level Anxiety And Prolong Duration Labor
Stage. Patients who will give birth had experience psychological problems that cause form the emotional reaction as the manifestation of psychological symptoms, the actions to be carried out either surgery or childbirth aid measures constitute a potential or actual threat to the integrity of someone who can evoke physiological and psychological stress. This emotional reaction usually is generally a negative reaction, such as refuse, fear, anger, sadness and anxiety. Giving deep breathing relaxation techniques in patients will be a decrease in tension, feeling amazingly beautiful in controlling body functions so that labor becomes smooth. Purpose of this study was to determine the effect of therapy on the breath in anxiety level and duration of labor. The design of this study using the pre and post-test only one group. analysis techniques with Wilcoxon test. using purposive sampling technique with 25 respondents. Univariate analysis results mean pre-test anxiety at 43.16 and the average post test by 31. The mean duration of first labor stage of the intervention group are 504 minutes and 564 minutes at control group. The Mean duration of second labor stage of the intervention group are 140 minutes and the control group was 57 minutes. Bivariate test results there is the influence between deep breathing relaxation therapy interventionswith anxiety with a $p$ value $=0.001$, there is the influence of deep breathing relaxation techniques with the duration of first labor stage with $p$ value $=0.001$, no effect of deep breathing relaxation with the duration of second labor stage with $p=0: 59$. In conclusion, there is the influence of deep breathing relaxation teraphi to anxiety and the duration of first stage of labor time, there is no influence teraphi relaxation with the duration of second labor stage.
\end{abstract}

Keywords: Deep Relaxation Therapy, Level Anxiety And Prolong Duration Labor Stage

Abstrak: Terapi Relaksasi Nafas Dalam, Tingkat Kecemasan Dan Lama Persalinan. Pasien yang akan melahirkan mengalami masalah-masalah psikologis yang berupa reaksi emosi sebagai menifestasi gejala psikologis,sebab tindakan yang akan dilakukan baik pembadahan maupun tindakan pertolongan persalinan marupakan ancaman potensial maupun aktual pada integritas seseorang yang dapat membangkitkan stress fisiologis maupun psikologis. Reaksi emosi ini biasanya pada umumnya berupa reaksi negatif, seperti menolak, takut, marah, sedih dan cemas. Pemberian teknik relaksasi nafas dalam pada pasien akan terjadi penurunan dalam ketegangan, perasaan luar biasa indah dalam mengontrol fungsi tubuh sehingga persalinan menjadi lancar. Tujuan Penelitian ini untuk mengetahui pengaruh terapi nafas dalam terhadap tingkat kecemasan dan lama persalinan. Rancangan penelitian ini menggunakan pre and post 
test only one group. Teknik Analisa data de ngan Uji Wilcoxon dan menggunakan Teknik sampling Purposive Consecutive sampling sejumlah 25 responden. Hasil analisa univariat rerata kecemasan pretest sebesar 43.16 dan rerata posttest sebesar 31 . Rerata lama salin kala 1 kelompok intervensi sebesar 504 menit kelompok control sebesar 564 menit, rerata lama salin kala 2 kelompok intervensi sebesar 140 menit kelompok control sebesar 57 menit. Hasil uji bivariat ada pengaruh antara intervensi terapi relaksasi nafas dalam terhadap kecemasan dengan nilai $\mathrm{p}=0.001$, ada pengaruh antara pemberian tehnik relaksasi nafas dalam terhadap lama kala 1 dengan nilai $\mathrm{p}=0.001$, tidak ada pengaruh pemberian relaksasi nafas dalam terhadap lama kala 2 dengan nilai $\mathrm{p}=0.59$. Simpulan, ada pengaruh antara teraphi relaksasi nafas dalam terhadap kecemasan dan lama persalinan kala 1, tidak ada pengaruh teraphi relaksasi nafas dalam terhadap lama persalinan kala 2.

Kata Kunci: Terapi Relaksasi Nafas Dalam, Tingkat Kecemasan Dan Lama Persalinan.

PENDAHULUAN

Persalinan adalah proses pengeluaran hasil konsepsi (janin dan uri) yang telah cukup bulan atau dapat hidup diluar kandungan melalui jalan lahir atau melalui jalan lain, dengan bantuan atau tanpa bantuan (kekuatan sendiri) (Manuaba, 1998:157).

Persalinan diartikan pula sebagai peregangan dan pelebaran mulut rahim. Kejadian itu terjadi ketika otot-otot rahim berkontraksi mendorong bayi keluar. Bersamaan dengan setiap kontraksi, kandung kemih, rectum, tulang belakang dan tulang pubic menerima tekanan kuat dari rahim. Berat dari kepala bayi ketika bergerak kebawah saluran lahir juga menyebabkan tekanan (Danuatmaja, B.2004:2).

Hal-hal tersebut menyebabkan terjadinya rasa nyeri pada ibu. Pada kala I persalinan murni nyeri dirasakan sebagi radiasi yang melintasi uterus dari daerah fundus ke punggung (Varney, H. 2001). Seorang ibu yang sedang menghadapi persalinan cenderung merasa takut, terutama pada ibu primigravida, sehingga rasa sakit saat persalinan akan lebih terasa.
Nyeri persalinan dapat mempengaruhi kontraksi uterus melalui sekresi kadar katekolamia dan kartisol yang menaikkan dan akibatnya mempengaruhi durasi persalinan. Nyeri juga dapat menyebabkan aktivitas uterus yang tidak terkoordinasi yang akan mengakibatkan persalinan lama. (Rosemary Mander, 2003), mengakibatkan peningkatan aktivitas sistem saraf simpatis, peruabahan tekanan darah, denyut jantung, pernafasan dengan warna kulit dan apabila tidak segera diatas I maka akan meningkatkan rasa khawatir, tegang, takut dan stress (Bobak, 2004).

Ibu yang akan melahirkan biasanya mengalami masalah-masalah psikologis yang berupa reaksi emosi sebagai menifestasi gejala psikologis,sebab tindakan yang akan dilakukan baik pembadahan maupun tindakan pertolongan persalinan marupakan ancaman potensial maupun aktual pada dan kondisi stress yang dialaminya, padahal sebenarnya individu dapat berpikiran positif, sehingga reaksi emosi yang muncul dapat berupa emosiemosi positif yang mengarah pada kesehatan fisik dan kesejahteraan mental. Rasa 
cemas ini merupakan keadaan mental yang tidak enak berkenaan dengan sakit yang mengancam atau yang dibayangkan, ditandai oleh kekhawatiran, ketidakenakan dan perasa tidak baik yang tidak dapat dihindari, disertai perasaan tidak berdaya karena menemui jalan buntu dan ketidak mampuan untuk menemukan pemecahan masalah terhadap masalah yang dihadapi (Stuart and Sundeen, 1998). Hal ini terjadi karena kebanyakan pasien persalinan kala I kurang mendapatkan informasi atau paparan yang akurat tentang persalinan khususnya pasien persalinan primipara sehingga pasien cenderung membuat interprestasi sendiri (self interpretation) yang kadang-kadang berlebihan, seperti bahwa persalinan sangat menyakitkan dan mengancam jiwa, akibat dari munculnya rasa cemas ini adalah meningkatnya sensitivitas (kepekaan) emosi individu dengan menifestasi mudah menangis dan mudah curiga (negative thingking) pada orang lain.

\section{METODE PENELITIAN}

Penelitian ini merupakan jenis penelitian quasi eksperimen dengan rancangan yang digunakan adalah pre and post test only one group. Sampel adalah sebagian ibu bersalin yang melahirkan di BPM wilayah Kabupaten Klaten diambil secara non probability sampling yaitu Consecutive sampling. Kriteria inklusi adalah Ibu bersalin kala I dan II, tidak ditunggui suami atau keluarga, Primipara dan bersedia menjadi responden. Kriteria eksklusi adalah Ibu bersalin kala I dan II dengan penyulit dan Ibu bersalin yang tidak bersedia menjadi responden. Instrumen penelitian menggunakan alat ukur Hamilton Rating Scale for Ansiety (HRS-A). Analisa Univariat dan Analisa Bivariat menggunakan Uji Wilcoxon dan
Uji Mann-whitney dengan Confidence Interval (CI) 95\% $(\alpha=0,05)$.

\section{HASIL PENELITIAN}

Hasil penelitian Pengaruh Terapi Relaksasi Nafas Dalam Terhadap Tingkat Kecemasan Dan Lama Persalinan Kala I Dan II Pada Primigravida Di BPM Wilayah Klaten secara diskriptif disajikan dalam table distribusi frekuensi di bawah ini.

Tabel 1.

Karakteristik Responden Berdasarkan Umur, Pekerjaan, Dan Pendidikan Responden

\begin{tabular}{|c|c|c|c|}
\hline No & Variabel & Frekuensi & $(\%)$ \\
\hline \multirow[t]{3}{*}{1} & Umur ibu saat & 4 & 16 \\
\hline & $\begin{array}{l}<20^{\text {th }} \\
\text { atau } \\
>35^{\text {th }}\end{array}$ & 21 & 84 \\
\hline & 2. $\begin{array}{l}20 \\
35^{\text {th }}\end{array}-$ & & \\
\hline \multirow[t]{3}{*}{2.} & Pekerjaan Ibu & & \\
\hline & $\begin{array}{l}\text { 1. Bekerja } \\
\text { di } \\
\text { rumah }\end{array}$ & $\begin{array}{c}24 \\
1\end{array}$ & $\begin{array}{c}96 \\
4\end{array}$ \\
\hline & $\begin{array}{l}\text { 2. Bekerja } \\
\text { di luar } \\
\text { rumah }\end{array}$ & & \\
\hline \multirow[t]{4}{*}{3} & Pendidikan ibu & & \\
\hline & 1. $\mathrm{SD}$ & 1 & 4 \\
\hline & 2. SMP & 15 & 60 \\
\hline & 3. SMA & 9 & 36 \\
\hline \multicolumn{2}{|c|}{ Jumlah } & 25 & 100 \\
\hline
\end{tabular}


Tabel 2

Kecemasan Responden Sebelum

Dilakukan Terapi Relaksasi Nafas Dalam Dan Sesudahnya

\begin{tabular}{|c|c|c|c|c|}
\hline \multirow[t]{2}{*}{ Karakteristik } & \multicolumn{2}{|c|}{$\begin{array}{l}\text { Skor cemas } \\
\text { Pre }\end{array}$} & \multicolumn{2}{|c|}{$\begin{array}{l}\text { Skor } \\
\text { cemas } \\
\text { post }\end{array}$} \\
\hline & $\mathbf{n}$ & $\%$ & $\mathbf{N}$ & $\%$ \\
\hline Rerata & 43.16 & & 31 & \\
\hline Nilai tengah & 49 & & 37 & \\
\hline Standar Deviasi & 11.9 & & 11.5 & \\
\hline Minimum & 10 & & 5 & \\
\hline Maksimum & 53 & & 46 & \\
\hline \multicolumn{5}{|l|}{ Tingkat cemas } \\
\hline \multicolumn{5}{|l|}{ - Ringan (skor <20) } \\
\hline \multicolumn{5}{|l|}{$\begin{array}{l}\text { - Sedang (skor } 21 \text { - } \\
\text { 27) }\end{array}$} \\
\hline \multicolumn{5}{|l|}{ - Berat (skor 28 - } \\
\hline \multirow{3}{*}{$\begin{array}{l}\text { - Berat sekali (skor } \\
\text { 42-56) }\end{array}$} & 2 & 8 & 1 & 4 \\
\hline & 3 & 12 & 15 & 60 \\
\hline & 18 & 72 & 4 & 16 \\
\hline \multirow[t]{2}{*}{ Total } & 25 & 100 & 25 & 10 \\
\hline & & & & 0 \\
\hline
\end{tabular}

Perlakuan teknik nafas dalam

banyak memberikan pengaruh penurunan tingkat kecemasan setelah diberi perlakuan selama 15 menit. Hal ini dapat dikatakan bahwa pemberian teknik nafas dalam efektif dilakukan untuk penurunan tingkat kecemasan pasien persalinan kala $\mathrm{I}$, rerata menunjukkan score $11,9 \mathrm{SD}=$ 43.16 dengan HAM-A (katagori cemas berat sekali ) menjadi cemas berat dengan SD 11.5=31, artinya ada perbedaan secara signifikan tingkat kecemasan pada ibu yang menjalani persalinan kala I antara sebelum diberi perlakuan teknik nafas dalam dan setelah diberikan teknik nafas dalam.

Data ini menunjukkan bahwa72 \% responden kelompok intervensi yang semula mengalami kecemasan dengan katagori tingkat berat, pada saat dilakukan post test menjadi 4\%, kondisi ini disebabkan karena responden memiliki peningkatan kemampuan dalam beradaptasi terhadap persalinan mereka, setelah enumerator melakukan intervensi kepada kelompok intervensi.

\section{PEMBAHASAN}

Perubahan kemampuan responden dalam beradaptasi terjadi karena adanya penambahan informasi pada diri responde melalui teknik relaksasi nafas dalam, membuat responden dan pasangan sangat terbantu dalam mengatasi kecemasan dan terjadi peningkatan rasa percaya diri pada responden sehingga responden menjadi lebih rileks dn mampu berfikir positif tentang persalinan yang dihadapi

Ada peningkatan proporsi kecemasan pada katagori cemas ringan dari $8 \%$ sebelum intervensi dna menjadi $20 \%$ post intervensi, dna juga $12 \%$ cemas dengan katagori cemas berat menjadi $60 \%$. Hal ini dikarenakan kemampuan adaptasi ibu dipengaruhi oleh presepsi yang dimiliki ibu terhadap kejadian yang menimpanya.

Stressor menyebabkan seseorang untuk berinteraksi untuk mempertahankan kesehatannya melalui mekanisme pemecahan masalah atau koping tertentu. Penyebab stress dapat berasal dari diri sendiri, diluar individu atau interaksi dengan orang lain. Pengaruh stressor serta kemampuan koping yang digunakan (Gaffar, 1999). Penurunan tingkat kecemasan pada pasien persalinan kala I sesudah diberikan perlakuan teknik nafas dalam sesuai dengan tori yang dikemukakan oleh Chilson (1997) menjelaskan bahwa pasien yang tidak mengalami penurunan tingkat kecemasan apabila kurang atau tidak mendapatkan informasi prosedur persalinan dan kecemasan pasien persalinan tersebut akan menurun apabila diberi informasi atau penjelasan yang kuat oleh tenaga 
kesehatan. Selain itu juga ada ahli yang menyatakan bahwa pasien yang telah mendapatkan penjelasan sebelum persalinan maka akan marasa lebih tenang dari hal-hal ini mengurangi rasa sakit, atau komplikasi lain setelah persalinan, disamping memperpendek lamanya perawatan di klinik bersalin. Dilihat dari uji statistik pada penelitian ini, dibandingkan dengan penelitian yang telah dilakukan sebelumnya didapatkan hasil yang sama, yaitu teknik nafas dalam efektif atau berpengaruh untuk menurunkan tingkat kecemasan pasien persalinan kala I dan II secara statistik berbeda.

Penelitian yang memperkuat hasil penelitian ini, adalah penelitian yang dilakukan oleh Abdul Ghofur dan Eko Purwoko (2011: 2) menghasilkan bahwa terdapat perbedaan secara signifikan tingkat kecemasan pada ibu yang menjalani persalinan kala I antara sebelum diberi perlakuan teknik nafas dalam dan setelah diberikan teknik nafas dalam $(\mathrm{p} \leq 0.05)$.

\section{KESIMPULAN DAN SARAN}

Skor kecemasan pada ibu persalinan kala 1 terjadi penurunan antara sebelum intervensi dan sesudahnya dengan rerata sebelum 43.16 dan rerata sesudah sebesar 31. Rerata lama persalinan kala 1 adalah 504 menit (8.4 jam), rerata lama persalinan kala 2 adalah 140 menit (2.3jam). Ada pengaruh pemberian terapi relaksasi nafas dalam terhadap kecemasan pada primigravida $(\mathrm{p}=0.000)$. Ada pengaruh pemberian terapi relaksasi nafas dalam terhadap lama kala 1 pada primigravida $(\mathrm{p}=0.001)$. Tidak ada pengaruh pemberian terapi relaksasi nafas dalam terhadap lama kala 2 pada primigravida $(\mathrm{p}=0.59)$. Saran untuk peneltiian ini, pelatihan relaksasi nafas dalam dapat menjadi salah satu alternatif intervensi yang digunakan untuk menurunkan kecemasan padaibu primipara. Proses persalinan merupakan hal yang fisiologis bagi setiap wanita. Tetapi sebagian wanita merasa takut karena rasa sakit yang muncul. Oleh karena itu teknik relaksasi dapat digunakan karena mudah dan tidak membutuhkan biaya. Sehingga ibu bersalin ini dapat beradaptasi dengan persalinannya. Persalinannya berjalan lancar, selamat ibu dan bayi. Dapat melanjutkan ke penelitian sejenis dengan memperbanyak jumlah sampel dan memperluas lahan penelitian dengan menggunakan metode yang tepat.

\section{DAFTAR RUJUKAN}

Bobak, et al. (2005) Buku Ajar : Keperawatan Maternitas. Jakarta : EGC.

Dahlan.S. (2012). Langkah - langkah Membuat Proposal Penelitian Bidang Kedokteran dan Kesehatan. Jakarta : Sangung Seto

Dahlan.S. (2011). Statistik Untuk Kedokteran dan Kesehatan. Jakarta : Salemba Medika

Danuatmaja, Bonny \& Mila. 2004. Persalinan normal tanpa rasa sakit. Jakarta: Puspa swara

Mander, Rosemari. (2004) Nyeri Persalinan. Alih Bahasa : Bertha Sugiarto. Jakarta : EGC.

Stuart G. W. Sundeen, S.J. 1998, Buku Saku Keperawatan Jiwa, edisi 3, ECG. Jakarta

Varney H, 2007. Buku Ajar Asuhan Kebidanan (Varneys Midwifery). Bab Graviditas. Jakarta: EGC. 